\title{
REFERENCES
}

1. The Bible translated by I. Ogienko. URL: https://bibleonline.ru/bible/rst66/rev/

2. Gruber, R (1960). General history of music. Moskva : Muz. Giz. 1 vol.

3. Rau, Ye. (2018) The genre of passion in the art of music: a common historical path and destiny in the XX-XXI centuries. Candidate's thesis, $\mathrm{S}-\mathrm{Pb}$.

4. Tkachenko, A. (2016). Ukrainian monody in the works of modern composers. Candidate's thesis, Lviv.

5. Yasinovskij, Yu. (2015). Musicology in modern scientific discourse or: Can the science of music become a university discipline in modern Ukraine. URL: http://er.ucu.edu.ua/bitstream/handle/1/658/Яciновський_Музикологія\%20в\%20сучасному\%20дискурсі.pdf?sequence=1\&isAllowed=y\%20(дата\%20 звернення:\% 2002.06.2020).

6. Das Lemberger Irmologion. (2008) Die alteste liturgische Musikhandschrift mit Funfiniennotation aus dem Ende des 16. Koln, Weimar, Wien: Bolau.

UDC $78.03+782.1$

DOI https://doi.org/10.31723/2524-0447-2020-30-1-8

\author{
$\mathrm{Du}$ Wei \\ ORCID: 0000-0003-3399-4278 \\ Applicant at the Department of Music History and Musical Ethnography \\ Odessa National A. V. Nezhdanova Academy of Music \\ WeiduOd19@gmail.com

\section{INTERACTION OF VERBAL AND MUSICAL SEMANTICS IN CHAMBER AND VOCAL CREATIVE WORK OF S. SLONIMSKY}

Research objective is to consider the principles of interaction between verbal and musical semantics in chamber and vocal music, highlighting the work of S. Slonimsky as the main object of study. Based on the study of a wide range of musicological studies, the artistic possibilities of the relationship between words and music as an artistic unity are revealed. The methodology of the work is based on an interdisciplinary comprehensive research framework, which includes the use of literary, musical and historical, musicological, analytical and semantic approaches. The scientific novelty is due to a holistic approach to the analysis of chamber and vocal creative work in the musical culture of the second half of the XX-early XXI centuries, which allows us to consider the ratio of the verbal and musical levels as a single composer's poetics. Conclusions. A prerequisite for the existence of the genre sphere of chamber vocal music is the relationship and constant dialogical interaction of two independent semiotic systems - word and music. Despite the many parameters that unite these two systems, we are still talking about two independent phenomena that have their own unique specifics and powerful artistic potential. In chamber and vocal creative work, the verbal and musical semiotic systems are united by a common artistic task, which becomes the basis for developing the principles of their interaction and the formation of a complex of stylistic parameters that allow the figurative and semantic content to be embodied.

The artistic synthesis of the verbal and musical levels in chamber and vocal music in general, and in the compositions of S. Slonimsky in particular, is primarily based on two most important features - on the one hand, on the fundamental closeness of musical and verbal language systems and on the relationship of the principles of organizing the intonation process, and on the other hand, on the difference in the possibilities of transferring the artistic-figurative and content components, which have a fundamentally different nature.

Key words: chamber and vocal creative work, musical hermeneutics, musical semantics, verbal semantics, musical content.

Вей Ду, здобувач кафедри історії музики та музичної етнографії Одеської національної музичної академії імені А. В. Нежданової

Взаємодія вербальної та музичної семантики в камерно-вокальній творчості С. Слонімського

Мета роботи - розгляд принципів взаємодії вербальної та музичної семантики в камерно-вокальній музиці, як головний об'єкт виділено вивчення творчості С. Слонімського. На основі розгляду широкого кола музикознавчих досліджень розкриваються художні можливості взаємозв'язку слова й музики як художньої єдності. Методологія дослідження грунтується на інтердисциплінарній комплексній основі, що предбачає використання літературознавчого, музично-історичного, музикознавчого аналітичного 
та семантичного підходів. Наукова новизна зумовлена цілісним підходом до аналізу камерно-вокальної творчості в музичній культурі другої половини XX-початку XXI століття, який дозволяє розглядати співвідношення вербального та музичного рівнів як єдину композиторську поетику. Висновки. Обов'язковою умовою існування жсанрової сфери камерно-вокальної музики стає взаємовідношення $і$ постійна діалогічна взаємодія двох самостійних семіотичних систем - слова і музики. Незважаючи на безліч параметрів, що об'єднують ці дві системи, усе же ідеться про два самостійні явища, щз мають власну унікальну специфіку і потужний художній потенціал. У камерно-вокальній творчості вербальна і музична семіотичні системи виявляються об'єднаними загальним художнім завданням, шо стає основою для формування принципів їх взаємодії і формування комплексу стилістичних параметрів та дозволяє втілитися образно-смисловому змісту.

Художній синтез словесного й музичного рівнів у камерно-вокальній музиці загалом $i$ у творчості С. Слонімського зокрема передусім грунтується на двох найважлливіших особливостях - з одного боку, на принциповій близькості музичної і вербальної мовної систем і на родинному зв'язку принципів організації процесу інтонування, з іншого - на відмінності в можливостях передачі художньо-образної $i$ змістової складових частин, щз має принципово іншу природу.

Ключові слова: камерно-вокальна творчість, музична герменевтика, музична семантика, вербальна семантика, музичний зміст.

Вей Ду, соискатель кафедры истории музыки и музыкальной этнографии Одесской национальной музыкальной академии имени А. В. Неждановой

Взаимодействие вербальной и музыкальной семантики в камерно-вокальном творчестве С. Слонимского

Цель работы - рассмотрение принципов взаимодействия вербальной и музыкальной семантики в камерно-вокальной музыке, выделяя в качестве главного объекта изучения творчество С. Слонимского. На основе рассмотрения широкого круга музыковедческих исследований раскрываются художественные возможности взаимосвязи слова и музыки как художественного единства. Методология исследования основывается на интердисииплинарной комплексной основе работы, включающей в себя использование литературоведческого, музыкально-исторического, музыковедческого аналитического и семантического подходов. Научная новизна обусловлена целостным подходом к анализу камерно-вокального творчества в музыкальной культуре второй половины XX - начала XXI века, который позволяет рассматривать соотношение вербального и музыкального уровней как единую композиторскую поэтику. Выводы. Обязательным условием существования жканровой сферы камерно-вокальной музыки становится взаимоотношение и постоянное диалогическое взаимодействие двух самостоятельных семиотических систем - слова и музыки. Несмотря на множество объединяюших эти две системы параметров, все жее речь идет о двух самостоятельных явлениях, имеющих собственную уникальную специфику и мощный художественный потенциал. В камерно-вокальном творчестве вербальная и музыкальная семиотические системы оказываются объединенными общим художественным заданием, что становится основой для вырабатывания принципов их взаимодействия и формирования комплекса стилистических параметров, позволяющих воплотиться образно-смысловому содержанию.

Художественный синтез словесного и музыкального уровней в камерно-вокальной музыке в целом и в творчестве С. Слонимского в частности в первую очередь основывается на двух важнейших особенностях - с одной стороны, на принципиальной близости музыкальной и вербальной языковой систем и на родстве принципов организации процесса интонирования, с другой - на различии в возможностях передачи художественно-образной и содержательной составляющих, имеющих принципиально отличную природу.

Ключевые слова: камерно-вокальное творчество, музыкальная герменевтика, музыкальная семантика, вербальная семантика, музыкальное содержание.

Relevance. In chamber and vocal creative work, from the moment of its inception and the formation of the functioning principles, the interrelation of the verbal and musical principles turns out to be a determining factor in the formation of the style appearance and stylistic devices of this direction. The style mobility that is characteristic of chamber vocal music is the result of constant dynamic interaction of two formative principles - typological, expressing a gravitation towards the formation of genre models and general principles of functioning, and individualized, in which a gravitation towards expressing personal experiences and feelings is manifested. These principles are decisive in the choice of artistic, dramatic and linguistic means, which makes it possible to build the figurative structure of chamber and vocal compositions as an artistic integrity and to ensure the interdependence of verbal and musical semantics. These and some other aspects of the study of chamber and vocal creative work still remain one of the most important tasks of modern musicology, since a number of issues related to the interpenetration and contamination of verbal and musical verbal complexes, which make it possible to reveal the complex specific nature of lyrics as a desire to reflect the world of feelings and experiences are still not fully resolved. The unique artistic and semantic and figurative and semantic content of chamber and vocal creative work provokes interest and attraction of attention to it from the side of researchers and the choice of the direction of musicologists and a wider circle of humanitarian researchers. 
The aim of the article is to consider the principles of interaction between verbal and musical semantics in chamber and vocal music, highlighting the work of S. Slonimsky as the main object of study. Based on the study of a wide range of musicological studies, the artistic possibilities of the relationship between words and music as an artistic unity are revealed. The methodology of the work is based on an interdisciplinary comprehensive research framework, which includes the use of literary, musical and historical, musicological, analytical and semantic approaches.

The scientific novelty is due to a holistic approach to the analysis of chamber and vocal creative work in the musical culture of the second half of the XX - early XXI centuries, which allows us to consider the ratio of the verbal and musical levels as a single composer's poetics.

Presenting the main material. The appeal to the semantic foundations of verbal and musical lyrics becomes decisive for the evolution of the composer's thinking, and the chamber and vocal industry as a whole is of major importance for the composer's national-style self-determination and the identification of specific artistic interests.

Since the beginning of the XX century, the problem and category of musical semantics has become one of the most discussed and demanded both in musicology and in other humanitarian research areas. As V. Kholopova points out in the article "Musical Hermeneutics, Musical Semantics, Musical Content: Comparison of Possibilities", the substantiation of the tasks of musical hermeneutics becomes the result of the activities of the German theoretical musician G. Krechmar, and the formation of the foundations of musical semantics belongs to B. Asafiev, who in his work of 1929 edition "Musical Form as a Process" first offered this definition [6, p. 20]. Like many other musicological terminological definitions, the category of musical semantics was borrowed in linguistics, "while in semiotics the isolation of semantics among the three parts of semiotics (syntactics - semantics - pragmatics) occurred later, only in 1938, in the book "Fundamentals of Sign Theory" by the American philosopher Charles William Morris" [6, p. 20]. As a kind of systemic unity, continuing the conceptual series of musical hermeneutics - musical semantics, V. Kholopova introduces another concept - musical content, which was proposed by the researcher herself in her work "Music as an art form" in 1980 [5].

The relationship between music and words as a special syncretic unity has repeatedly become the subject of consideration by various musicologists and researchers, among whom there was one of the first who raised this problem - B. Asafiev. The special musicological attitude to the verbal level is largely based on the fact that music as a materialized form of creativity, as well as the musical form "as the process of intonation" formed in the course of the musical-creative process, were born in syncretic union with the word [1].

All major musical genres need a word - both in connection with synthetic forms and in connection with headings (subheadings) that suggest the etymology of autonomous compositional decisions. The word participates in music in the form of a program, including literary and poetic, prefaces, comments "in the margins" of musical notation, in the form of literary - epistolary, memoir, critical, instructive and technological - composer opuses that reveal the content of the musical concept. A kind of dialogue between the composer and the performer can be considered a system of musical remarks as author's comments-recommendations addressed to the performer, with the help of which a more accurate reproduction of the artistic-figurative side of the composition is possible. And the verbal component of musical creative work exists as a necessary verbal discussion of the historical experience of music in the unity of its aesthetic, composer and performing sides, as a theory of musical creativity with its own conceptual reserve.

In the works of A. Samoilenko, musical semantics is considered as a "border area between all participants in the musical-creative process", which is addressed "to the relationships that have psychological importance and stability between them. Thus, it borders between understanding and interpretation of music - it "brings" understanding to the possible boundaries of interpretation" [4, p. 52].

The researcher notes that interpretation should be understood as a single act of understanding, a characteristic of which can be the fact that there can be no literal repetition of an interpretation once carried out. In other words, its uniqueness, as well as the fact that it occurs within the indicated sign boundaries, is concrete, it insists on its uniqueness and claims to be complete and finished in the representation of the chosen object [4, p. 52]. At the same time, interpretation can be perceived as a process of a new reproduction of the interpreted composition, especially when it comes to the relationship between the verbal and musical levels of the composition, since the word becomes an obligatory vehicle of meaning in music, thereby generating new semantic structures and semantic contexts. Based on such conclusions, one can conclude that the word is one of the central elements of any cultural process, since only those meanings that acquire verbal expression are most noticeably manifested in it, that means, they are recorded as a verbal and semantic 
structure. This is also explained by the fact that semantic content always needs a verbal-expressed form, since it is through it that it is possible to clarify the main intentions and reveal all aspects of human participation in musical culture.

Along with this, in order to identify and understand any cultural and historical process as an integral structure, "ethical and aesthetic assessments, personal and semantic attitudes, indicating the complementarity of the rational-logical and sensually-irrational (intuitive) ways of cognition, about the functional significance of the fideistic relationships for the formation of human activity positions" [3, p. 207].

The process of finding the verbal expression of musical semantics or the verbalization of musical meanings can be attributed to the "self-growing logos" of musical art mentioned by Heraclitus [2].

Therefore, the study of the symbolic experience of musical culture, which finds its expression in verbal form and substantiates the significance of the word for the cultural and historical process as a whole, is becoming the subject of particular importance in modern musicological studies. As A. Samoilenko points out, "in musical culture, which musicological knowledge should be recognized of, the word also becomes a means of verifying musically sounded meanings, that is, a proof of the importance and truth of musical meanings. Actually, the revealed musical semantics is the pronunciation of the significant units of music in the word, endowing them with "names" - the nominative layer of musical content" [4, p. 51].

Chamber and vocal creative work is becoming one of the most indicative genres in which the interaction of musical and verbal components is decisive from the point of view of structural-compositional, form-building and artistic and semantic parameters. A prominent representative of the musical culture of the second half of the XX century, Sergei Slonimsky, allocates a prominent place in his creative heritage to chamber and vocal genres. It should be noted that the neo-folklore tendency is one of the most prominently expressed and goes beyond the chamber and vocal genre in the composer's work. Among the extensive creative heritage of S. Slonimsky, an appeal to folklore sources and traditions and folk epics of various countries is a stable stylistic feature. The works that characterize this direction in the composer's work include: the vocal scene "Farewell to a Friend in the Desert" (1966), which is based on one of the oldest literary compositions and the most ambitious composition written in cuneiform - the ancient Eastern legend "The Epic of Gilgamesh", or poem "About everything that has seen"; "Monologues from Ancient Eastern Lyrics" (1967), which came out in 1999 under the title "From the Old Testament. Psalms of David. Monologues. For high voice, oboe, French horn and harp. Song of Songs of Solomon. Lyrical fragment. For soprano, tenor, chamber choir, oboe, horn and harp"; "Spring has come" (1958) on the verses of Japanese poets, and many others.

The appeal to texts so significant for world culture did not become an obstacle for the composer to use the most relevant composition techniques for the XX century, among which there are dodecaphonic and serial methods, sonoristics, principles of microintervalics. These, and many other techniques, are used by S. Slonimsky in order to create compositions of both neo-folklore direction, and in compositions not related to folklore themes or images borrowed from ancient epics.

Chamber and vocal creative work of S. Slonimsky is based on the wide use of timbre characteristics and performance capabilities of instruments and voice, which sometimes find themselves in a completely unexpected neighborhood - in addition to a broad interpretation of genre possible chamber and vocal music, the composer resorts to an unexpected arrangement of performers. An example of such a selection of the composition of performers in a chamber and vocal creative work can be the "Stanzas of the Dhammapada" (flute, harp, percussion), "Monologues from ancient Eastern lyrics" (oboe, harp, horn), "Songs of the Troubadours" (ensemble of block-flutes and lute), "Merry Songs" (piccolo flute, tuba, percussion), and the choice of specific instruments is always conditioned either by the desire to recreate the timbre picture of the depicted historical period, or by questions of artistic imagery originating in the relationship between the verbal and musical levels in the composition.

Artistic imagery and the associated metric structure of the primary source of poetry, refracting through the prism of S. Slonimsky's composer's thinking, form special stylistic devices and musical and linguistic foundations. Among the most important authors of poetic texts for S. Slonimsky are A. Akhmatova, O. Mandelstam, A. Blok, M. Lermontov, F. Tyutchev and many others. The gravitation towards choosing as the basis of poetic compositions brings the chamber and vocal lyrics of the composer closer to the stylistic parameters and stylistic devices of urban romance and romance lyrics of the XIX century. Unlike other chamber and vocal compositions, which could be based on both poetic and prose texts, in the romance lyrics of S. Slonimsky there is a completely traditional "set" of ensembles - voice and piano. 
In "Romances on the Verses of A. Akhmatova", "Six romances on the Verses of O. Mandelstam" there is a gravitation towards the structural and compositional foundations of the Russian urban romance with its verse form, simple and transparent textured pattern of the piano part and melodization of the vocal part in combination with bright individually - the author's style of the composer. At the same time, in the later compositions of S. Slonimsky, namely in "Ten Poems by A. Akhmatova", in "Four Poems by O. Mandelstam", in "Prayer" on poems by M. Lermontov and many others, there is a significant complication of the piano texture, which includes timbre diversity, colorful musical-shaped effects, virtuoso figurations with a large register coverage, which make these compositions by S. Slonimsky related to chamber and vocal compositions by P. Tchaikovsky, S. Rachmaninov, etc.

Speaking about the noticeable relationship of the chamber and vocal creative work of S. Slonimsky with the above-mentioned traditions of the Russian romance of the XIX century, it should be clarified that the similarity between them is observed both in the internal structuring of his constructions, in the variants of the composition of the musical stanza, and in the compositional foundations and musical and dramatic aspects of romances structure in general, where it is clear at all levels - from working with the verbal text and the influence of the verbal component on the formation of melodic structures, to the embodiment of artistic images - there is a reliance on the principles of classical thinking. This is reflected in the methods of thematic and harmonic development, in the principles of texture and melodic solutions, in the peculiarities of the intonation formation of the vocal part, which in many cases is close to an arious characteristic, as well as in the methods of interaction of the vocal part and its instrumental accompaniment.

S. Slonimsky addresses a wide range of authors - creators of poetic texts, including the poetic word of the most iconic representatives of his era and unshakable authorities in this area A. Pushkin, M. Lermontov, A. Blok, A. Akhmatova, O. Mandelstam, S. Yesenin, as well as the composer, turns to the art of his contemporaries, whose poetry was consonant with the artistic and aesthetic attitudes of S. Slonimsky himself - the poetry of N. Rubtsov, E. Rein A. Gorodnitsky and A. Kushner.

It should be noted that in musical art at the turn of the XX-XXI centuries there are significant changes in the traditional ideas about the chamber and vocal genre and about the functions of melody in it, which leads to a significant revision of a number of established positions in this genre sphere, concerning the principles of intonation development, the peculiarities of the harmonic structure, the rhythmic organization of the material, timbre and sound and color characteristics.

The melodism of S. Slonimsky, associated with the intonation content of the music, can be regarded as the most natural way for a composer to express musical thought. The compositional poetics of S. Slonimsky is characterized by a synthetic type of melody, which summarizes the actual and most artistically significant, including in the intonation sphere, trends in the composer's creativity of the second half of the XX - early XXI centuries. The originality and extraordinary "freshness" of the musical language of S. Slonimsky is a consequence of his adherence to such multi-level genre and style phenomena as folklore, ancient epic, monody, Medieval-Renaissance modality, from which the composer drew his ideas throughout his creative biography. The gravitation towards vocal intonation, which is interpreted by the composer as a necessary quality, as the basis of the principle of thematism and a characteristic feature of the entire system of the composer's musical and linguistic means, not only for chamber vocal, operatic, but also instrumental compositions.

Conclusions. A prerequisite for the existence of the genre sphere of chamber vocal music is the relationship and constant dialogical interaction of two independent semiotic systems - word and music. Despite the many parameters that unite these two systems, we are still talking about two independent phenomena that have their own unique specifics and powerful artistic potential. In chamber and vocal creative work, the verbal and musical semiotic systems are united by a common artistic task, which becomes the basis for developing the principles of their interaction and the formation of a complex of stylistic parameters that allow the figurative and semantic content to be embodied.

The artistic synthesis of the verbal and musical levels in chamber and vocal music in general, and in the compositions of S. Slonimsky in particular, is primarily based on two most important features - on the one hand, on the fundamental closeness of musical and verbal language systems and on the relationship of the principles of organizing the intonation process, and on the other hand, on the difference in the possibilities of transferring the artistic-figurative and content components, which have a fundamentally different nature.

The search for one's own musical language with all the obligatory language components from spelling, phonology, lexicology to morphology, syntax and semantics - is one of the most 
important creative tasks of S. Slonimsky, which he managed to solve in many ways. Any musical and verbal text that the composer is working on reveals one extremely important feature - its potential openness and inclination to establish intertextual connections with other textual devices, which makes it possible to consider the entire composition of the composer as a single metatext.

\section{BIBLIOGRAPHY}

1. Асафьев Б. Музыкальная форма как процесс. Ленинград : Музыка, 1971. 376 с.

2. Осадчая С. Православная певческая традиция как «самовозрастающий логос». Музична творчість та наука в історичному просторі: Київьке музикознавство. Національна музична академія України імені П.І. Чайковського. Київ, 2008. Вип. 73. С. 88-96.

3. Осадчая С. Триада эстетического-этического-фидеистического как основополагающий принцип музыкальной культуры. Музичне мистеитво $і$ культура : науковий вісник Одеської національної музичної академії імені А.В. Нежданової. Одеса : Астропринт, 2014. Вип. 19. С. 202-212.

4. Самойленко А. Диалог как музыкально-культурологический феномен: методологические аспекты современного музыкознания: дис. ... докт. искусствоведения. Одесса, 2002. 434 с.

5. Холопова В. Музыка как вид искусства : учебное пособие. Москва : Лань, 2014. 320 с.

6. Холопова В. Музыкальная герменевтика, музыкальная семантика, музыкальное содержание: сравнение возможностей. Уиеные записки Российской академии музыки имени Гнесиных. Москва, 2015. Вып. 1 (12). С. 20-28.

\section{REFERENCES}

1. Asafiev, B. (1971) Musical form as a process. L.: Muzyka. [in Russian].

2. Osadchaya, S. (2008) Orthodox singing tradition as a "self-growing logos". Musical creative work as a science in the historical space: Kyiv Musical Science. NMAU names after P.I. Tchaikovsky. K. Num. 73. [in Russian].

3. Osadchaya, S. (2014) The aesthetic-ethical-fideistic triad as a fundamental principle of musical culture. Musical mystery and culture: Science newsletter of the Odessa National Musical Academy named after A.V. Nezhdanova. Odesa: Astroprint. Num. 19. [in Russian].

4. Samoilenko, A. (2002) Dialogue as a musical and cultural phenomenon: methodological aspects of modern musicology: dis ... of Doctor of Art History. Odessa. [in Russian].

5. Kholopova, V. (2014) Music as an art form. Tutorial. Moscow: Lan’. [in Russian].

6. Kholopova, V. (2015) Musical hermeneutics, musical semantics, musical content: comparison of possibilities. Scientific notes of the Russian Academy of Music named after the Gnesin. M.: Russian Academy of Music named after the Gnesin. Num. 1 (12). [in Russian]. 